\title{
Variation in Lipid Composition of Apples in Relation to Watercore
}

\author{
Shiow Y. Wang and Miklos Faust \\ Fruit Laboratory, Beltsville Agriculture Research Center, Agriculture Research Service, U.S. \\ Department of Agriculture, Beltsville, MD 20705
}

Additional index words. Malus domestica, fatty acids, glycolipids, phospholipids, sterols

\begin{abstract}
The glycolipids, phospholipids, and sterols were determined in normal and watercore-affected apple (Malus domestica Borkh. cv. Delicious). Fruit with watercore contained higher amounts of glycolipids, phospholipids, and sterols. The ratios of unsaturated to saturated fatty acids and (18:3) to $(18: 1+18: 2)$ were lower in watercore-affected tissue than in normal tissue. The ratio of free sterols to phospholipids was higher, whereas the ratio of phosphatidylcholine to phosphatidylethanolamine was lower in watercore-affected apple. Membrane lipids were altered in watercore-affected fruit.
\end{abstract}

Watercore is a physiological disorder of apples. The afflicted tissues appear water-soaked and translucent. The disorder is usually associated with the vascular bundles of the core line, although the condition may exist as spots throughout the entire fruit (Fisher, 1923; Marlow and Loescher, 1984; Olsen et al., 1962; Williams, 1966). The metabolic aspects of watercore in apples include an elevated water content, decreased reducing sugars and soluble pectin, increased anaerobic products, and a higher sorbitol content than normal tissue (Atkinson, 1971; Marlow and Loescher, 1984; Williams, 1966). Fruit with watercore also produce more ethylene and contain higher amounts of putrescine, spermidine, 1-aminocyclopropane-1-carboxylic acid (ACC), and 1-(malonylamino)cyclopropane-1-carboxylic acid (Wang and Faust, 1992). The activities of ACC synthase and ethylene-forming enzyme in watercore-affected fruit are also higher than in normal fruit (Wang and Faust, 1992). These phenomena are consistent with the concept that apples with watercore are more advanced physiologically than normal fruit (Brooks and Fisher, 1926).

Cell membranes appear to play an important role in the regulation of plant metabolism (Hellergren et al., 1984). The physical state of the membrane lipids could determine the physiological functioning of plant tissue (Brenner, 1984; Raison and Chapman, 1976; Wang, 1982). Changes in the proportions and composition of lipids in plant cell membranes are thought to play a role in ripening and senescence by altering the physical properties of the lipid matrix (Lurie and Ben-Arie, 1983; Thompson et al., 1982; Wojciechowski, 1980). During apple ripening, osmophilic bodies are visible through the electron microscope (Faust, 1989). These osmophilic bodies are thought to be composed of lipids and appear in advanced stages of maturity and ripening (Faust, 1989). Bartley (1985) reported that phospholipid content increased dramatically, while sterol changed very little during apple fruit ripening. However, earlier work with apples indicated that little change occurred in the phospholipid compostion of the fruits during ripening, but that the sterol concentration increased substantially (Galliard, 1968; Mazliak, 1969). Kollas (1968) found watercored tissue had a higher rate of leakage of sorbitol and glucose than nonwatercored tissue, suggesting that membrane integrity may be altered in watercored tissue (Kollas, 1968; Marlow and Loescher, 1984). The present study was undertaken to determine whether the lipid composi-

Received for publication 17 Dec. 1991. Accepted for publication 13 Apr. 1992. The cost of publishing this paper was defrayed in part by the payment of page charges. Under postal regulations, this paper therefore must be hereby marked advertisement solely to indicate this fact. tion in watercored tissues differ from those in normal fruit tissues.

\section{Materials and Methods}

Apple fruit were harvested from 10 eight-year-old apple trees in late Sept. 1990 from an orchard at Beltsville, Md. About $22 \%$ of the fruit exhibited watercore symptoms. Skin and flesh samples were collected from normal apples and watercore affected fruit. Triplicate samples of $30.0 \mathrm{~g}$ fresh weight each were taken from 300 fruit and used for lipid analyses. Flesh tissue from the watercored fruit was separated into affected and nonaffected samples. Methods for the extraction, fractionation, and analysis of lipids were described by Wang et al. (1988). Purified lipids were separated into neutral, glyco-, and phospholipid fractions by silicic-acid column chromatography on 100- to 200mesh Bio Sil A (Bio Rad Laboratories, Richmond Calif.). The glycolipid and phospholipid fractions were further separated by thin layer chromatography (TLC) on $20 \times 20-\mathrm{cm}$ glass plates precoated with a $250 \mu \mathrm{m}$ thickness of silica gel 60 (EM Reagents, Darmstadt, Germany) using 100 acetone : 2 acetic acid : 1 water (by volume; for glycolipids) and 85 chloroform : 15 methanol : 10 acetic acid : 3.5 water (by volume; for phospholipids). Individual galactolipids and phosholipids were identified by cochromatography with authentic standards (Sigma, St. Louis, and Supelco, Bellefonte, Pa.) and by detection with spray reagents specific for hexose sugars (Christie, 1973) or phosphate (Dittmer and Lester, 1964). Individual lipid bands were scraped off and eluted in 2 chloroform : 1 methanol (v/v). Total fatty acids esterified to polar lipids from apple tissues were derivatized to fatty acid methyl esters (FAME) for flame ionization detection-gas chromatography (FID-GC) analysis (Wang et al., 1988). n-Heptadecanoic acid was included in all samples as an internal standard, and methyl heptadecanoate was used as an external standard. Individual FAME were identified by a comparison of retention times with those of authentic standards (Supelco). This tentative identification of major polar lipid fatty acids was corroborated by gas chromatography-mass spectrometry (GC-MS) (Wang et al., 1988).

The neutral lipid fraction from apple tissues was dried under

Abbreviations: CI, chemical ionization; DGDG, digalactosyl diglyceride; EI, electron impact; FAME, fatty acyl methyl esters; FID, flame ionization detector; GC-MS, gas chromatography-mass spectrometry; MDGD, monogalactosyl diglyceride; PC, phosphatidylcholine; PE, phosphatidylethanolamine; PG, phosphatidylglycerol; PI, phosphatidylinositol; TLC, thin-layer chromatography. 
Table 1. Glycolipid, phospholipid, and sterol content from skin and flesh tissues of normal and watercore-affected 'Delicious' apples. ${ }^{2 y}$

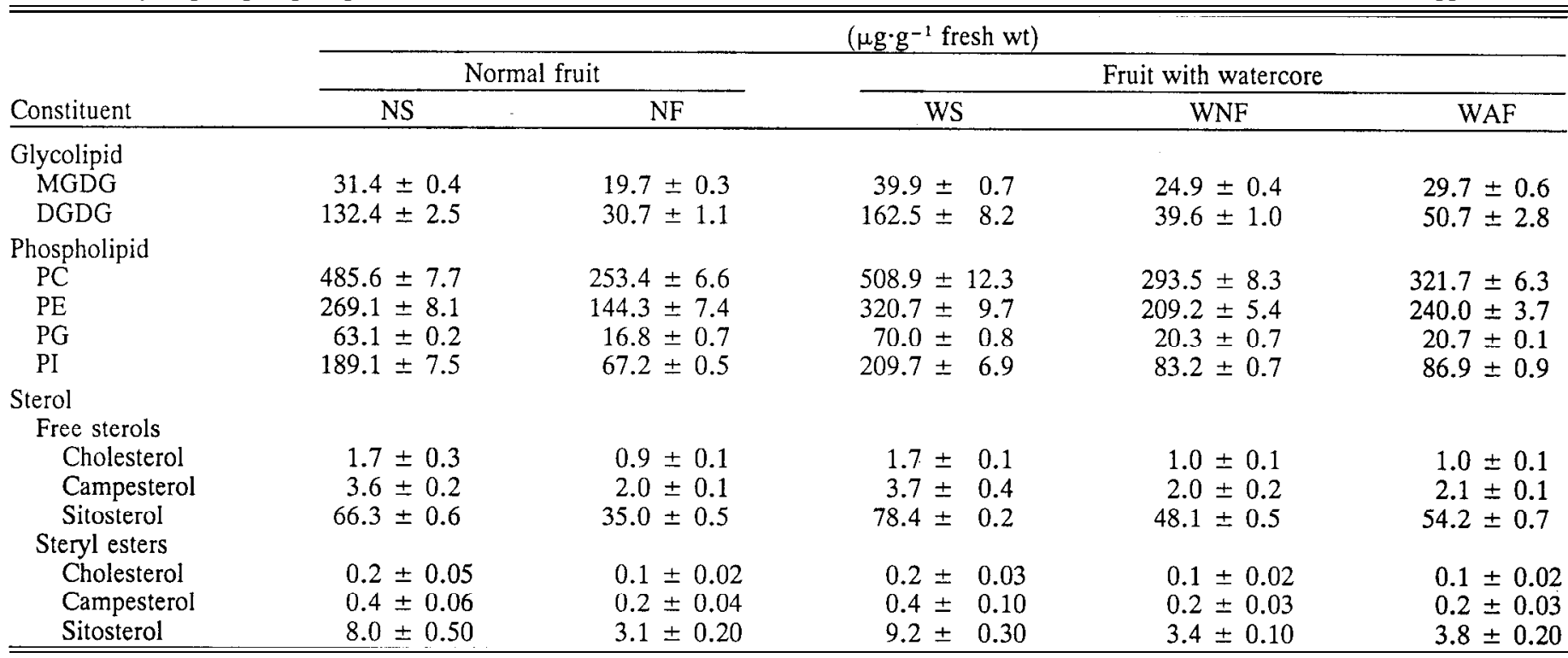

${ }^{7}$ Mean of three replicates \pm SE.

"Abbreviations: NS, normal skin; NF, normal flesh; WS, skin from apples with watercore; WNF, apples with watercore, normal flesh; WAF, apples with watercore, affected flesh.

Table 2. Fatty acid composition (weight percentage of total) of glycolipids (MGDG and DGDG) from skin and flesh tissues of normal and watercore-affected 'Delicious' a p p le. . $^{z, y}$

\begin{tabular}{|c|c|c|c|c|c|}
\hline \multirow{3}{*}{$\begin{array}{l}\text { Constituent } \\
\text { fatty acids }\end{array}$} & \multicolumn{5}{|c|}{$\begin{array}{l}\text { Percentage of total } \\
\text { fatty acids }\end{array}$} \\
\hline & \multicolumn{2}{|c|}{$\begin{array}{c}\text { Normal } \\
\text { fruit }\end{array}$} & \multicolumn{3}{|c|}{$\begin{array}{c}\text { Fruit } \\
\text { with } \\
\text { watercore }\end{array}$} \\
\hline & NS & $\mathrm{NF}$ & WS & WNF & WAF \\
\hline \multicolumn{6}{|l|}{ MGDG } \\
\hline $16: 0$ & $4.4 \pm 0.5$ & $9.2 \pm 0.8$ & $6.6 \pm 0.5$ & $14.1 \pm 0.7$ & $17.6 \pm 0.9$ \\
\hline $18: 0$ & $2.8 \pm 0.1$ & $0.7 \pm 0.1$ & $3.5 \pm 0.4$ & $2.0 \pm 0.1$ & $2.8 \pm 0.1$ \\
\hline $18: 1$ & $3.7 \pm 0.4$ & $2.1 \pm 0.2$ & $4.2 \pm 0.3$ & $2.4 \pm 0.2$ & $2.9 \pm 0.1$ \\
\hline $18: 2$ & $33.5 \pm 1.2$ & $11.1 \pm 0.6$ & $36.7 \pm 0.6$ & $30.0 \pm 1.3$ & $36.7 \pm 0.7$ \\
\hline $18: 3$ & $55.6 \pm 1.1$ & $76.9 \pm 1.5$ & $49.0 \pm 0.7$ & $51.5 \pm 1.2$ & $40.0 \pm 1.0$ \\
\hline \multicolumn{6}{|l|}{ DGDG } \\
\hline $16: 0$ & $10.1 \pm 0.4$ & $16.6 \pm 0.4$ & $15.1 \pm 1.0$ & $16.8 \pm 1.0$ & $18.1 \pm 0.6$ \\
\hline $18: 0$ & $10.9 \pm 0.3$ & $6.9 \pm 0.2$ & $11.4 \pm 0.8$ & $7.0 \pm 0.4$ & $7.9 \pm 0.5$ \\
\hline $18: 1$ & $4.1 \pm 0.2$ & $2.3 \pm 0.1$ & $5.7 \pm 0.3$ & $3.1 \pm 0.2$ & $3.4 \pm 0.5$ \\
\hline $18: 2$ & $28.7 \pm 1.0$ & $18.7 \pm 1.0$ & $32.0 \pm 1.1$ & $25.4 \pm 0.9$ & $27.3 \pm 1.0$ \\
\hline $18: 3$ & $46.2 \pm 1.5$ & $55.5 \pm 1.6$ & $35.8 \pm 1.2$ & $47.7 \pm 1.3$ & $43.3 \pm 1.1$ \\
\hline
\end{tabular}

${ }^{7}$ Mean of three replicates \pm SE.

${ }^{y}$ Abbreviations: NS, normal skin; NF, normal flesh; WS, skin from apple with watercore;

WNF, apples with watercore, normal flesh; WAF, apples with watercore, affected flesh.

a stream of $\mathrm{N}_{2}$ and redissolved in $2 \mathrm{ml}$ of hexane. Silicic-acid column chromatography (100- to 200-mesh Bio Sil A, Bio Rad Laboratories) was used to separate the steryl ester and free sterols by elution with 10 hexane : 1 ether (v/v; steryl ester) and 2 hexane : 1 ether (v/v; free sterols). Steryl ester was cleaved to free sterol by saponification $(1 \mathrm{M} \mathrm{KOH}$ in $80 \%$ ethanol for $1 \mathrm{~h}$ at $80 \mathrm{C}$ under $\mathrm{N}_{2}$ ) and hexane extraction. Lathosterol (cholest7-en- 3 $\beta$ - ol) was added to each sample as an internal standard. Free sterols were precipitated with digitonin (Sigma). The digitonides were collected on a glass fiber filter (Reeve Angel, Clifton, N.J.) and washed with 1 acetone : 2 diethyl ether (v/ v). Free sterols were liberated from the digitonides by refluxing in $1 \mathrm{ml}$ of pyridine for $30 \mathrm{~min}$ at $100 \mathrm{C}$. After the samples had cooled, $1 \mathrm{ml}$ of deionized, distilled water was added, and the free sterols were recovered by extraction with $2 \mathrm{ml}$ of hexane. Sterol composition was determined by FID-GC and further confirmed by GC-MS (Wang et al., 1988). Means of three replicate samples with SE are reported.

\section{Results and Discussion}

The lipid composition in apple fruit was dominated by galacto- and phospholipid in skin and flesh tissues (Table 1). Digalactosyl diglyceride (DGDG) was the major galactolipid, with more than twice the amount of monogalactosyl diglyceride (MGDG) in the skin. Phosphatidylcholine (PC) and phosphatidylethanolamine $(\mathrm{PE})$ represented a higher percentage of the 
Table 3. Fatty acid composition (weight percentage of total) of phospholipids (PC, PG, PE, PI) from skin and flesh tissues of normal and watercore-affected 'Delicious' apple. ${ }^{z, y}$

\begin{tabular}{|c|c|c|c|c|c|}
\hline \multirow{3}{*}{$\begin{array}{l}\text { Constituent } \\
\text { fatty acids }\end{array}$} & \multicolumn{5}{|c|}{$\begin{array}{l}\text { Percentage of total } \\
\text { fatty acids }\end{array}$} \\
\hline & \multicolumn{2}{|c|}{ Normal fruit } & \multicolumn{3}{|c|}{$\begin{array}{l}\text { Fruit with } \\
\text { watercore }\end{array}$} \\
\hline & NS & NF & WS & WNF & WAF \\
\hline \multicolumn{6}{|l|}{$\mathrm{PC}$} \\
\hline $16: 0$ & $12.0 \pm 0.6$ & $21.0 \pm 1.1$ & $12.9 \pm 0.5$ & $22.8 \pm 1.0$ & $24.0 \pm 0.9$ \\
\hline $18: 0$ & $10.0 \pm 0.3$ & $4.3 \pm 0.4$ & $11.1 \pm 0.3$ & $4.4 \pm 0.3$ & $4.5 \pm 0.2$ \\
\hline $18: 1$ & $3.3 \pm 0.1$ & $2.5 \pm 0.2$ & $3.8 \pm 0.4$ & $3.0 \pm 0.4$ & $3.1 \pm 0.3$ \\
\hline $18: 2$ & $54.4 \pm 1.1$ & $57.6 \pm 1.2$ & $56.2 \pm 1.2$ & $59.0 \pm 1.5$ & $61.4 \pm 1.2$ \\
\hline $18: 3$ & $20.3 \pm 0.9$ & $14.6 \pm 0.7$ & $16.0 \pm 0.7$ & $10.8 \pm 1.1$ & $7.0 \pm 0.5$ \\
\hline \multicolumn{6}{|l|}{$P E$} \\
\hline $16: 0$ & $12.9 \pm 0.5$ & $29.1 \pm 0.9$ & $13.9 \pm 0.4$ & $30.5 \pm 0.8$ & $30.4 \pm 0.9$ \\
\hline 18:0 & $8.5 \pm 0.2$ & $2.9 \pm 0.1$ & $9.6 \pm 0.3$ & $3.2 \pm 0.2$ & $3.4 \pm 0.1$ \\
\hline $18: 1$ & $1.3 \pm 0.1$ & $1.4 \pm 0.1$ & $1.8 \pm 0.1$ & $1.7 \pm 0.1$ & $1.9 \pm 0.1$ \\
\hline $18: 2$ & $62.5 \pm 1.6$ & $57.4 \pm 1.8$ & $65.7 \pm 1.5$ & $60.3 \pm 1.4$ & $61.4 \pm 1.2$ \\
\hline $18: 3$ & $14.8 \pm 0.8$ & $9.2 \pm 0.6$ & $9.0 \pm 0.6$ & $4.3 \pm 0.2$ & $2.9 \pm 0.1$ \\
\hline \multicolumn{6}{|l|}{ PG } \\
\hline $16: 0$ & $42.8 \pm 1.4$ & $47.4 \pm 1.6$ & $43.2 \pm 1.3$ & $48.3 \pm 1.7$ & $49: 4 \pm 1.2$ \\
\hline $18: 0$ & $4.7 \pm 0.2$ & $2.3 \pm 0.1$ & $5.2 \pm 0.1$ & $3.2 \pm 0.1$ & $3.1 \pm 0.1$ \\
\hline $18: 1$ & $19.0 \pm 0.5$ & $14.8 \pm 0.3$ & $20.0 \pm 0.4$ & $15.2 \pm 0.1$ & $16.3 \pm 0.2$ \\
\hline $18: 2$ & $23.1 \pm 0.7$ & $23.7 \pm 0.5$ & $25.1 \pm 0.7$ & $26.1 \pm 0.5$ & $27.5 \pm 0.6$ \\
\hline $18: 3$ & $10.4 \pm 0.2$ & $11.8 \pm 0.4$ & $6.5 \pm 0.2$ & $7.2 \pm 0.3$ & $3.7 \pm 0.2$ \\
\hline \multicolumn{6}{|l|}{ PI } \\
\hline $16: 0$ & $23.9 \pm 0.6$ & $38.7 \pm 0.7$ & $26.1 \pm 0.5$ & $41.3 \pm 1.1$ & $42.5 \pm 1.2$ \\
\hline 18:0 & $12.8 \pm 0.3$ & $1.9 \pm 0.1$ & $14.5 \pm 0.4$ & $2.1 \pm 0.2$ & $2.2 \pm 0.1$ \\
\hline $18: 1$ & $1.6 \pm 0.1$ & $1.1 \pm 0.1$ & $1.8 \pm 0.1$ & $1.2 \pm 0.1$ & $1.1 \pm 0.2$ \\
\hline $18: 2$ & $48.6 \pm 1.4$ & $40.1 \pm 0.8$ & $46.7 \pm 1.2$ & $47.1 \pm 1.3$ & $48.5 \pm 1.3$ \\
\hline $18: 3$ & $13.1 \pm 0.5$ & $18.2 \pm 0.3$ & $10.9 \pm 0.7$ & $8.3 \pm 0.6$ & $5.7 \pm 0.3$ \\
\hline
\end{tabular}

${ }^{z}$ Mean of three replicates \pm SE.

yabbreviations: NS, normal skin; NF, normal flesh; WS, skin from apples with watercore; WNF, apples with watercore, normal flesh; WAF, apples with watercore, affected flesh.

Table 4. Ratio of unsaturated to saturated fatty acids $[(18: 1+18: 2$ $+18: 3) /(16: 0+18: 0)]$ in glycolipids and phospholipids from skin and flesh tissues of normal and watercore-affected 'Delicious' apple. $^{\mathrm{z}}$

\begin{tabular}{lcccccc}
\hline & \multicolumn{5}{c}{ Unsaturated/saturated } \\
\cline { 2 - 3 } \cline { 5 - 6 } Constituent & \multicolumn{2}{c}{ Normal fruit } & & \multicolumn{3}{c}{ Fruit with watercore } \\
\cline { 2 - 3 } \cline { 5 - 7 } & NS & NF & & WS & WNF & WAF \\
\hline Glycolipid & & & & & \\
MGDG & 12.89 & 9.10 & & 8.90 & 5.20 & 3.90 \\
DGDG & 3.76 & 3.26 & 2.77 & 3.20 & 2.80 \\
Phospholipid & & & & & \\
PC & 3.55 & 2.95 & & 3.17 & 2.68 & 2.51 \\
PE & 3.67 & 2.13 & & 3.26 & 1.97 & 1.96 \\
PG & 1.11 & 1.01 & 1.07 & 0.94 & 0.90 \\
PI & 1.72 & 1.46 & 1.30 & 1.30 & 1.24
\end{tabular}

${ }^{2}$ Abbreviations: NS, normal skin; NF, normal flesh; WS, skin from apples with watercore, normal flesh; WAF, apples with watercore, affected flesh.

phospholipid in apple. Apple skin contained more galacto- and phospholipids than flesh. Tissue with watercore contained more galacto- and phospholipid than normal tissue (Table 1).

The fatty acid profiles of galacto- and phospholipids from apple skin and flesh were similar and relatively unsaturated (Tables 2 and 3). Palmitic (C 16:0), stearic (C 18:0), oleic (C 18:1),
Table 5. Ratio of linolenic to linoleic plus oleic acids [(18:3)/(18:2 $+18: 1)$ ] in glycolipids and phospholipids from skin and flesh tissues of normal and watercore-affected 'Delicious' apples at harvest.

\begin{tabular}{llllll}
\hline \hline & \multicolumn{5}{c}{$(18: 3) /(18: 2+18: 1)$} \\
\cline { 2 - 3 } \cline { 5 - 7 } Constituent & Normal fruit & \multicolumn{3}{c}{ Fruit with watercore } \\
\cline { 2 - 3 } \cline { 5 - 7 } NS & NF & & WS & WNF & WAF \\
\hline Glycolipid & & & & & \\
MGDG & 1.49 & 5.83 & 1.20 & 1.58 & 1.01 \\
DGDG & 1.41 & 2.64 & 0.95 & 1.67 & 1.41 \\
Phospholipid & & & & & \\
PC & 0.35 & 0.24 & 0.27 & 0.17 & 0.11 \\
PE & 0.23 & 0.16 & 0.13 & 0.07 & 0.05 \\
PG & 0.25 & 0.31 & 0.14 & 0.17 & 0.08 \\
PI & 0.26 & 0.44 & 0.17 & 0.17 & 0.11 \\
\hline \hline
\end{tabular}

${ }^{2}$ Abbreviations: NS, normal skin; NF, normal flesh; WS, skin from apples with watercore; WNF, apples with watercore, normal flesh; WAF, apples with watercore, affected flesh.

linoleic (C 18:2), and linolenic acid (C 18:3) were the predominant fatty acids. Identification of these fatty acid esters was confirmed by GC-MS. The full electron impact (EI) mass spectra of fatty acid esters was similar to the authentic standard, as reported (Heller and Milne, 1978). The FAME of palmitate, stearate, oleate, linoleate, and linolenate derived from extracted 
Table 6. Ratios of free sterols/phospholipids, PC/PE and (cholesterol + campesterol)/sitosterol from skin and flesh tissues of normal and watercore-affected 'Delicious' apples.'

\begin{tabular}{|c|c|c|c|c|c|}
\hline \multirow[b]{3}{*}{ Constituent } & \multicolumn{5}{|c|}{ Ratio } \\
\hline & \multicolumn{2}{|c|}{ Normal fruit } & \multicolumn{3}{|c|}{ Fruit with watercore } \\
\hline & NS & NF & WS & WNF & WAF \\
\hline$(\text { Free } \text { sterols).(phospholipids })^{-1}$ & 0.071 & 0.079 & 0.076 & 0.084 & 0.086 \\
\hline$(\mathrm{PC}) \cdot(\mathrm{PE})^{-1}$ & 1.800 & 1.770 & 1.590 & 1.400 & 1.340 \\
\hline 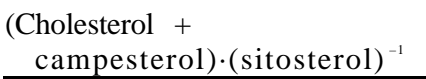 & 0.080 & 0.083 & 0.069 & 0.071 & 0.056 \\
\hline
\end{tabular}

${ }^{2}$ Abbreviations: NS, normal skin; NF, normal flesh; WS, skin from apples with watercore; WNF, apples with watercore, normal flesh; WAF, apples with watercore, affected flesh.

galacto- and phospholipids were also confirmed by selected ionmonitoring using the molecular ions $\mathrm{M}^{+}$and quasimolecular ions $(\mathrm{M}+1)^{+}$in $\mathrm{EI}$ and chemical ionization $(\mathrm{CI})$, respectively. The molecular ions $\mathrm{M}^{+}$in $\mathrm{EI}$ of palmitate, stearate, oleate, linolate, and linoleate were 270, 298, 296, 294, and 292, respectively. The quasimolecular ions $(\mathrm{M}+1)^{+}$in $\mathrm{CI}$ of palmitate, stearate, oleate, linolate, and linoleate were 271, 299, 297, 295, and 293, respectively. The GC-MS relative retention time of these fatty acids were also identical to the relative retention times of authentic samples.

Linolenic acid was the predominant fatty acid in MGDG and DGDG (Table 2), while linoleic acid was the predominant fatty acid in PC, PE, and phosphatidylinositol (PI).

Phosphatidylglycerol (PG) and PI contained a relatively higher amount of the saturated fatty acid, palmitic acid (C 16:0), than of other phospholipids (Table 3). The degree of fatty acid unsaturation in MGDG was much higher than that in DGDG (Table 4). PC and PE were less saturated than PG and PI (Table 4). There was a corresponding increase in the percentage of the saturated lipids in the watercored tissue. The ratios of unsaturated $(18: 1+18: 2+18: 3)$ to saturated $(16: 0+18: 0)$ and (18:3) to $(18: 1+18: 2)$ of galacto- and phospholipids were lower in watercore-affected tissue than in normal tissue (Tables 4 and 5). This result perhaps reflects the depletion of unsaturated fatty acids by lipid peroxidation (Hariyadi and Parkin, 1991) or changes in lipid metabolism in watercore-affected tissue. Different lipid components may have specific roles in maintaining membrane structure and function. Fatty acid unsaturation is one of the key factors regulating membrane function (Dickens and Thompson, 1982). The decrease of this ratio may contribute to a decrease in the fluidity of membranes in watercore-affected fruit.

A high content of sterols and sterol esters is characteristic for the plasma membrane of plant cells. These steryllipids serve to stabilize the lipid bilayer. Changes in sterol level and composition have been shown to affect membrane permeability and development in higher plants (Goad, 1983). A large increase in the content of steryl lipids, as well as a dramatic change in their sterol composition, occurs with ripening in apple (Galliard, 1968) and tomato (Lycopersicon esculentum Mill.) (Chow and Jen, 1978). The free sterols in apple fruit are $\beta$ - sitosterol, cholesterol, and campesterol. The identity of these sterols was established by gas-liquid chromatography (GLC) and mass spectrometry. The GLC-MS relative retention times, the fragmentation patterns, and the significant ions and relative intensities of the full EI-MS of these sterols matched the authentic standards, as reported (Heller and Mime, 1978; Sawai et al., 1978). $\beta$ - Sitosterol is the major desmethylsterol in apple fruit, comprising $>90 \%$ of the sterol present. Cholesterol and cam- pester01 are present in $\approx 2 \%$ and $4 \%$, respectively. Stigmasterol was not detected. The major esterified sterol, sitosterol, was present in apple skin and flesh. Steryl esters of campesterol and cholesterol were also present in trace amounts (Table 1). Steryl esters may also modulate membrane properties (Goad, 1983; Grunwald, 1975). The apple skin contained higher amounts of free sterols and steryl esters than flesh (Table 1). There was a concentration difference in sterol content in skin or flesh between normal and watercore-affected apples. Tissue with watercore contained more sterol and steryl esters than normal tissue (Table 1). The lipid composition of the various membranes of plant cells greatly affects the fluidity of their lipid matrix (Brockerhof, 1974). The interaction of free sterols with phospholipids may affect membrane function and permeability (Grunwald, 1975). The ratio of free sterols to phospholipids was higher, whereas the ratios of PC to PE and cholesterol + campesterol to sitosterol were lower in watercored tissue (Table 6 ). These results indicate a decrease in the fluidity of membranes in watercore-affected tissue. This phenomenon is similar to that which occurs in ripening or senescence (Legge et al., 1986). In this respect, apples with watercore may be regarded as more advanced physiologically than normal apples.

Taken together, our study showed that watercore-affected fruit contains more glycolipids, phospholipids, and sterols than normal fruit. It has a higher ratio of free sterols to phospholipids and lower ratios of PC to PE and cholesterol + campesterol to sitosterol. All of these factors contribute to a lower membrane fluidity in watercored tissue and may reflect accelerated senescence.

\section{Literature Cited}

Atkinson, J.D. 1971. Diseases of tree fruits in New Zealand. Dept. Scientific Ind. Res., Auckland, New Zealand.

Bartley, I.M. 198.5. Lipid metabolism of ripening apples. Phytochemistry $24: 2857-2859$.

Brenner, R.R. 1984. Effect of unsaturated acids on membrane structure and enzyme kinetics. Prog. Lipid Res. 23:69-96.

Brockerhof, H. 1974. Model of interaction of polar lipids, cholesterol, and proteins in biological membranes. Lipids 9:645-650.

Brooks, C. and D.F. Fisher. 1926. Water-core of apples. J. Agr. Res. 32:223-260

Christie, W.W. 1973. Lipid analysis, p. 107-108. Pergamon, Oxford, England.

Chow, E.T.S. and J.J. Jen. 1978. Phytosterol biosynthesis in ripening tomatoes. J. Food Sci. 43:1424-1426.

Dickens, B.F. and G.A. Thompson, Jr. 1982. Phospholipid molecular species alterations in microsomal membranes as initial key step during cellular acclimation to low temperature. Biochemistry 21:36043611 .

Dittmer, J.C. and R.L. Lester. 1964. A simple specific spray for the 
detection of phospholipids on thin-layer chromatograms. J. Lipid Res. 5:126-127.

Faust, M. 1989. Physiology of temperate zone fruit trees. Wiley, New York.

Fisher, D.F. 1923. Water core. Proc. Washington State. Assoc. 19:98104.

Galliard, T. 1968. Aspects of lipid metabolism in higher plants-II. Phytochemistry 7:1915-1922.

Goad, L.J. 1983. How is sterol synthesis regulated in higher plants? Biochem. Soc. Trans. 11:548-552.

Grunwald, C. 1975. Plant sterols. Annu. Rev. Plant Physiol. 26:209236.

Hariyadi, P. and K.L. Parkin. 1991. Chilling-induced oxidative stress in cucumber fruits. Postharvest Biol. Technol. 1:33-45.

Heller, S.R. and G.W.A. Milne. 1978. EPA/NIH mass spectral data base (vol. 4): Molecular weights 381-1674. U.S. Govt. Printing Office, Washington, D.C., p. 3439-3551.

Hellergren, J., T. Lundborg, and S. Widell. 1984. Cold acclimation of Pinus sylvestris: Phospholipids in purified plasma-membranes from needles of pine. Physiol. Plant. 62:162-166.

Kollas, D.A. 1968. Physiology of watercore development in apple. $\mathrm{PhD}$ Thesis, Cornell Univ., Ithaca, N.Y.

Legge, R.L., K.H. Cheng, J.R. Lepock, and J.E. Thompson. 1986. Differential effects of senescence on the molecular organization of membranes in ripening tomato fruit. Plant Physiol. 81:954-959.

Lurie, S. and R. Ben-Arie. 1983. Microsomal membrane changes during the ripening of apple fruit. Plant Physiol. 73:636-638.

Marlow, G.C. and W.H. Loescher. 1984. Watercore. Hort. Rev. 6:189251.
Mazliak, P. 1969. Le metabolism des lipides au tours de la maturation des pommes. Qual. Plant Mat. Veg. 19:19-53.

Olsen, K., H.A. Schemer, and G.S. Birth. 1962. Detection and evaluation of watercore in apples by light transmittance. Proc. Washington State Hort. Assn. 58:195-197.

Raison, J.K. and E.A. Chapman. 1976. Membrane phase changes in chilling sensitive Vigna radiata and their significance to growth. Austral. J. Plant Physiol. 3:291-299.

Sawai, K., T. Taibo, and T. Okuno. 1978. Biochemical studies on apple fruits. V. Presence of three sterols in the pulp of apple fruits. Bul. Faculty Agr. Hirosaki Univ. 30:1-6.

Thompson, J.E., S. Mayak, M. Shinitzky, and A.H. Halevy. 1982. Acceleration of membrane senescence in cut carnation flowers by treatment with ethylene. Plant Physiol. 69:859-863.

Wang, C.Y. 1982. Physiological and biochemical responses of plants to chilling stress. HortScience 17:173-186.

Wang, S.Y. and M. Faust. 1992. Ethylene biosynthesis and polyamine accumulation in apples with watercore. J. Amer. Soc. Hort. Sci. 117:133-138.

Wang, S.Y., T. Sun, B.D. Whitaker, and M. Faust. 1988. Effect of paclobutrazol on membrane lipids in apple seedlings. Physiol. Plant. 73:560-564.

Williams, M.W. 1966. Relationship of sugars and sorbitol to watercore in apples. Proc. Amer. Soc. Hort. Sci. 88:67-75.

Wojciechowski, Z.A. 1980. Biosynthesis of sterol conjugates in plants, p. 405-414. In: P. Mazliak, P. Benveniste, C. Costes, and R. Deuce (eds.). Biogenesis and function of plant lipids. Elsevier/North-Holland, Amsterdam, The Netherlands. 